\title{
Ecological role of large benthic decapods in marine ecosystems: a review
}

\author{
Stephanie A. Boudreau*, Boris Worm \\ Biology Department, Dalhousie University, 1355 Oxford Street, PO Box 15000, Halifax, Nova Scotia B3H 4R2, Canada
}

\begin{abstract}
Large benthic decapods play an increasingly important role in commercial fisheries worldwide, yet their roles in the marine ecosystem are less well understood. A synthesis of existing evidence for 4 infraorders of large benthic marine decapods, Brachyura (true crabs), Anomura (king crabs), Astacidea (clawed lobsters) and Achelata (clawless lobsters), is presented here to gain insight into their ecological roles and possible ecosystem effects of decapod fisheries. The reviewed species are prey items for a wide range of invertebrates and vertebrates. They are omnivorous but prefer molluscs and crustaceans as prey. Experimental studies have shown that decapods influence the structuring of benthic habitat, occasionally playing a keystone role by suppressing herbivores or space competitors. Indirectly, via trophic cascades, they can contribute to the maintenance of kelp forest, marsh grass, and algal turf habitats. Changes in the abundance of their predators can strongly affect decapod population trends. Commonly documented nonconsumptive interactions include interference-competition for food or shelter, as well as habitat provision for other invertebrates. Anthropogenic factors such as exploitation, the creation of protected areas, and species introductions influence these ecosystem roles by decreasing or increasing decapod densities, often with measurable effects on prey communities. Many studies have investigated particular ecosystem effects of decapods, but few species were comprehensively studied in an ecosystem context. A simplified synthetic framework for interpreting ecosystem roles of decapods was derived from the available evidence; however, more experimental and long-term observational studies are needed to elucidate mechanisms and shed light on the longterm consequences of decapod fisheries.
\end{abstract}

KEY WORDS: Lobster $\cdot$ Crab $\cdot$ Trophic cascade $\cdot$ Keystone $\cdot$ Ecosystem effects $\cdot$ Anthropogenic effects $\cdot$ Species interactions

Resale or republication not permitted without written consent of the publisher

\section{INTRODUCTION}

Large crustaceans are becoming increasingly important to coastal and continental shelf fisheries (Anderson et al. 2011, Steneck et al. 2011). For example, in eastern North America, a well-documented shift has occurred from groundfish, such as Atlantic cod Gadus morhua, to invertebrates that now dominate commercial landings and value (Worm \& Myers 2003, Frank et al. 2005). Globally, commercial catches of crustaceans have increased $\sim$-fold since 1950 and are the only invertebrate group that continues to trend upward in recent years (Anderson et al. 2011). Yet, when compared to finfish, there is a much smaller knowledge base available from which to manage these fisheries, particularly in an ecosystem context (Anderson et al. 2008). Large mega-decapods, defined here as decapod crustaceans with a carapace length (CL) or width (CW) of $>10 \mathrm{~cm}$, such as American lobster Homarus americanus and snow crab 
Chionoecetes opilio, have become particularly important commercial species in the Northwest (NW) Atlantic region and elsewhere. Decapod crustaceans have a global distribution and can be found in most habitats, ranging from intertidal to deep water regions. Their importance to humans is well documented and frequently discussed (Steneck et al. 2011), however we are only beginning to understand the role that decapods play in marine ecosystems, and how exploitation might modify this role.

Interest in the ecological effects of fisheries often tends to focus on large apex predators and their role in the ecosystem (e.g. Pauly et al. 1998, Jackson et al. 2001, Frank et al. 2005, Heithaus et al. 2008, Baum \& Worm 2009, Estes et al. 2011). One of the commonly described ecosystem effects of fishing marine predators has been an increase in benthic invertebrates, including large decapod crustaceans (Baum \& Worm 2009, Boudreau \& Worm 2010). On occasion large decapods may replace large fish (e.g. Atlantic cod) as the dominant predator, the ecological impacts of which are poorly understood (e.g. Steneck et al. 2011). One well-documented example is a shift in the NW Atlantic ecosystem's trophic structure in the 1980s to 90 s due to the depletion of top predators. Here, an observed decline in groundfish abundance (largely due to overexploitation) was followed by a large increase in benthic decapods and other prey species, likely because of predation release (Steneck et al. 2004, Worm \& Myers 2003, Frank et al. 2005). In contrast, the North Pacific Ocean currently yields low decapod abundance (e.g. king crab Paralithodes camtschaticus, snow crab Chionoecetes opilio, and shrimp Pandalus spp.) due to population collapses in the early 1980s (Orensanz et al. 1998). These populations have since been slow to recover. As decapod stocks were low in Alaska, the biomass of groundfish (i.e. Walleye pollock Theragra chalcogramma) increased to an all-time high (Ianelli et al. 2011). This suggests that there may be a suite of conditions within an oceanic system that, once altered by fishing, are better suited for supporting decapod crustaceans or large-bodied groundfish (Worm et al. 2007). Yet, the broader ecological consequences of such changes in decapod populations on the benthic ecosystem are less well understood.

Many studies have focused on the diet of large marine decapods, but little is known about the strength of predatory interactions, their cascading, and overall ecosystem effects. Predation generally plays a strong role in structuring marine benthic communities (Shurin et al. 2002), ranging from intertidal shores (e.g. Paine 1994) to the deep sea (e.g.
Micheli et al. 2002), but few experimental studies have focused on large decapods. Decapods are typically quite mobile, undergo ontogenetic habitat changes over their life cycle, and show a progressive dietary shift with increasing size (Sainte-Marie \& Chabot 2002). It is therefore likely that they would affect a range of habitat and prey types over their life cycle.

In this paper we attempt to synthesize what is known about the role of large benthic decapods (lobsters and large crabs) in marine ecosystems. Specifically we review their multiple roles as (1) prey, (2) predators and keystone species, as well as (3) nonconsumptive interactions. Finally, given the large role humans play in modifying natural systems (Estes et al. 2011), we ask how anthropogenic factors modify the ecosystem role of decapods, and how future research efforts could provide deeper insights into these questions.

\section{METHODS}

The above questions are addressed by synthesizing the existing evidence from mega-decapod populations worldwide. A literature search was conducted using the Web of Knowledge database and the following keywords: decapod ecosystem effect (52 results), lobster ecosystem effect (109), crab ecosystem effect (347), lobster diet (456), and crab diet (1570). These papers, as well as references cited therein, form the basis of this review. Specifically, we were interested in case studies of the different roles all species of mega-decapod (CL or CW $>10 \mathrm{~cm}$ ) play in oceanic ecosystems. However, the majority of the mega-decapods studied in the literature were of commercial value, hence this review is necessarily biased towards those species.

Available publications employed a variety of methods including decapod exclusion experiments in the field (e.g. Quijon \& Snelgrove 2005b), experimental transplants (e.g. Robles \& Robb 1993), tethering experiments (e.g. Silliman \& Bertness 2002), and diet studies (e.g. Jewett \& Feder 1982). These were used primarily to gain mechanistic insights into potential predator-prey mechanisms and interactions. Experiments in the laboratory were also used, often in concert with field observations and surveys. Non-consumptive interactions were studied using similar methods as those listed above, e.g. observations on collected animals (e.g. Dvoretsky \& Dvoretsky 2008), field (e.g. Novak 2004) and lab experiments to observe interactions (e.g. Williams et al. 2006), or a 
combination of field and lab studies (e.g. Jones \& Shulman 2008). At larger spatial and temporal scales, time series analyses were used to complement smaller-scale mechanistic studies. These might examine ecosystem changes occurring in the wake of decapod exploitation (e.g. Lafferty 2004, Shears et al. 2006) or recovery (e.g. Babcock et al. 1999).

\section{SPECIES}

The species addressed in this paper are large benthic invertebrates of the order Decapoda, belonging to the following infraorders: Brachyura (true crabs), Anomura (king crabs), Astacidea (clawed lobsters) and Achelata (clawless lobsters). Most of these species are well known, largely due to their commercial value (Table 1).

Most of the brachyurans included in this review, with the exception of the tanner crab Chionoecetes bairdi and Dungeness crab Metacarcinus magister (formerly Cancer magister) (north Pacific Ocean), are native to the northwestern Atlantic Ocean, such as the blue crab Callinectes sapidus, snow crab Chionoecetes opilo (co-occurs in the north Pacific), and the rock crab Cancer irroratus. Also mentioned are the Jonah crab Cancer borealis and green crab Carcinus maenas. The green crab is the smallest decapod described here, reaching a maximum CW of 9 to $10 \mathrm{~cm}$ (Klassen \& Locke 2007). Originally native to Europe it was introduced to eastern North America in the 19th century (Grosholz \& Ruiz 1996) and has since been identified as one of the world's most invasive marine species (Lowe et al. 2000). Part of its success may be due to lower rates of parasitism and larger size in its introduced range (Torchin et al. 2001). The green crab's range, habitat, and prey field overlaps with important commercial species in the NW Atlantic, namely American lobster, rock and Jonah crabs. Its interactions will be discussed within this context.

King crabs (Family Lithodidae) belong to one of the youngest decapod families (Thatje et al. 2005) and may have originally evolved from hermit crabs (Cunningham et al. 1992). Red king crab Paralithodes camtschaticus is possibly one of the largest extant arthropods; large individuals can weigh $>10 \mathrm{~kg}$ and measure up to $22 \mathrm{~cm}$ in CL. This species is native to the northeastern Pacific Ocean where it is commercially harvested. It has also been introduced into the Barents Sea. Other lithodids discussed here include the northern stone crab Lithodes maja, stone crab Paralomis spp., and Neolithodes spp.
Clawed lobsters discussed here are the American lobster Homarus americanus native to the NW Atlantic Ocean and the European lobster H. gammarus in the northeast Atlantic. Clawless lobsters include several species of spiny lobster, such as Panulirus interruptus (California), P. marginatus (Hawaii), and Caribbean $P$. argus (Florida, Bahamas), and the spiny rock lobsters Jasus edwardsii (New Zealand), P. cygnus (western Australia), and J. lalandii (South Africa).

There are important morphological differences between the crabs, clawed and clawless lobsters included in this study. Whether a species has claws influences how it interacts with habitat, conspecifics, predators and prey. For example, the American lobster's claws allows it to manipulate substrates for shelter, establish rank, capture prey and defend itself (Lawton \& Lavalli 1995). Clawed lobsters are often aggressive (Scrivener 1971), and form dominance hierarchies (Karnofsky \& Price 1989, Atema \& Voight 1995). In clawless lobsters, defensive structures are limited to their robust antenna and armoured carapace (Atema \& Cobb 1980, Barshaw et al. 2003), and they are often associated with conspecifics (Herrnkind 1969).

\section{ECOSYSTEM EFFECTS}

\section{Mega-decapods as prey}

Most of the large decapods considered here (Table 1) have relatively few predators once they become adults due to their large size and armoured carapaces; yet they can be very vulnerable to predation at earlier life stages. In addition to humans, some fish, birds, marine mammals and cephalopods are known to prey on these species at various stages.

Examples of fish predators include the Nassau grouper Epinephelus striatus (Eggleston et al. 1997) and grey triggerfish Balistes capriscus (Lavalli \& Herrnkind 2009), which both prey on the Caribbean spiny lobster Panulirus argus; Pacific cod Gadus macrocephalus prey on snow crabs Chionoecectes spp. (Jewett 1982); and sculpins Myoxocephalus spp. consume benthic stages of American lobsters (e.g. Hanson \& Lanteigne 2000, Hanson 2009, Boudreau \& Worm 2010). Cephalopods and sharks are also reported to prey on decapods, for example the Caribbean reef octopus Octopus briareus occasionally consumes P. argus (e.g. Berger \& Butler 2001, Butler \& Lear 2009) and the leopard shark Triakis semifasciata preys on Dungeness crab (third most important prey item; Ebert \& Ebert 2005). 
Table 1. Examples of studies examining ecological roles of large marine decapods. Indicated are regions of study, common and scientific names of the decapod species, type of interaction, nature of the evidence, and sources. Listed alphabetically by scientific name

\begin{tabular}{|c|c|c|c|}
\hline Region & Common name(s) & Scientific name(s) & Interaction \\
\hline Beaufort Inlet, North Carolina; NW Atlantic & Blue crab & Callinectes sapidus & Host \\
\hline Back Sound, North Carolina; NW Atlantic & Blue crab & Callinectes sapidus & Predator \\
\hline Sapelo Island, Georgia; NW Atlantic & Blue crab & Callinectes sapidus & Keystone predator \\
\hline $\begin{array}{l}\text { Casco Bay, Maine to Chesapeake Bay, Virginia; } \\
\text { NW Atlantic }\end{array}$ & Blue crab, green crab & $\begin{array}{l}\text { Callinectes sapidus, Carcinus } \\
\text { maenas }\end{array}$ & Predator, prey \\
\hline Chesapeake Bay, Maryland; NW Atlantic & Blue crab & Callinectes sapidus & Cannibalism \\
\hline Monterey Peninsula, California; NE Pacific & Cancer crab & Cancer spp. & Prey \\
\hline NE Newfoundland; NW Atlantic & Snow crab & Chionoecetes opilio & Predator \\
\hline Bonne Bay, Newfoundland; NW Atlantic & Snow crab & Chionoecetes opilio & Predator \\
\hline Bonne Bay, Newfoundland; NW Atlantic & Snow crab & Chionoecetes opilio & Predator \\
\hline $\begin{array}{l}\text { Alaska, Japan, Russia; North Pacific } \\
\text { Gulf of St. Lawrence: NW Atlantic }\end{array}$ & Snow crab, tanner crab & Chionoecetes opilio, C. bairdi & Prey \\
\hline Bonne Bay, Newfoundland; NW Atlantic & Snow crab, rock crab & $\begin{array}{l}\text { Chionoecetes opilio, } \\
\text { Cancer irroratus }\end{array}$ & Predator \\
\hline Gulf of Maine; NW Atlantic & $\begin{array}{l}\text { American lobster, } \\
\text { rock crab, green crab }\end{array}$ & $\begin{array}{l}\text { Homarus americanus, Cancer } \\
\text { irroratus, Carcinus maenas }\end{array}$ & Predator \\
\hline SW Nova Scotia; NW Atlantic & American lobster & Homarus americanus & Predator \\
\hline Narragansett Bay, Rhode Island; NW Atlantic & $\begin{array}{l}\text { American lobster, } \\
\text { Jonah crab }\end{array}$ & $\begin{array}{l}\text { Homarus americanus, } \\
\text { Cancer borealis }\end{array}$ & Competitor \\
\hline Isle of Shoals, New Hampshire; NW Atlantic & $\begin{array}{l}\text { American lobster, } \\
\text { Jonah crab }\end{array}$ & $\begin{array}{l}\text { Homarus americanus, } \\
\text { Cancer borealis }\end{array}$ & Predator \\
\hline Gulf of Maine; NW Atlantic & $\begin{array}{l}\text { American lobster, } \\
\text { rock crab }\end{array}$ & $\begin{array}{l}\text { Homarus americanus, } \\
\text { Cancer irroratus }\end{array}$ & Niche segregation \\
\hline Passamaquoddy Bay, New Brunswick; NW Atlantic & $\begin{array}{l}\text { American lobster, } \\
\text { rock crab }\end{array}$ & $\begin{array}{l}\text { Homarus americanus, } \\
\text { Cancer irroratus }\end{array}$ & Predator \\
\hline $\begin{array}{l}\text { Northumberland Strait, Southern Gulf of } \\
\text { St. Lawrence; NW Atlantic }\end{array}$ & $\begin{array}{l}\text { American lobster, } \\
\text { rock crab }\end{array}$ & $\begin{array}{l}\text { Homarus americanus, } \\
\text { Cancer irroratus }\end{array}$ & Predator, prey \\
\hline Magdalen Islands, Gulf of St. Lawrence; NW Atlantic & $\begin{array}{l}\text { American lobster, } \\
\text { rock crab }\end{array}$ & $\begin{array}{l}\text { Homarus americanus, } \\
\text { Cancer irroratus }\end{array}$ & Predator, prey \\
\hline Magdalen Islands, Gulf of St. Lawrence; NW Atlantic & $\begin{array}{l}\text { American lobster, } \\
\text { rock crab }\end{array}$ & $\begin{array}{l}\text { Homarus americanus, } \\
\text { Cancer irroratus }\end{array}$ & Predator, prey \\
\hline Southern Gulf of St. Lawrence; NW Atlantic & $\begin{array}{l}\text { American lobster, } \\
\text { rock crab }\end{array}$ & $\begin{array}{l}\text { Homarus americanus, } \\
\text { Cancer irroratus }\end{array}$ & Host, vector \\
\hline Southern Gulf of St. Lawrence; NW Atlantic & $\begin{array}{l}\text { American lobster, } \\
\text { green crab }\end{array}$ & $\begin{array}{l}\text { Homarus americanus, } \\
\text { Carcinus maenas }\end{array}$ & Competitor \\
\hline Lundy no-take zone, UK; NE Atlantic & European lobster & Homarus gammarus & Abundance \\
\hline $\begin{array}{l}\text { Tawharnui and Mimiwhangata Marine Parks, } \\
\text { New Zealand; SW Pacific }\end{array}$ & Spiny rock lobster & Jasus edwardsii & Trophic cascade \\
\hline Leigh Reserve, New Zealand; SW Pacific & Spiny rock lobster & Jasus edwardsii & Trophic cascade \\
\hline Saldanha Bay Reserve, South Africa; SE Atlantic & Rock lobster & Jasus lalandii & Predator, prey \\
\hline Antarctic Bellingshausen Sea, Southern Ocean & King crab & $\begin{array}{l}\text { Lithodes spp., Paralomis spp., } \\
\text { Neolithodes spp. }\end{array}$ & Predator \\
\hline Bamfield, Britsh Columbia; NE Pacific & Dungeness crab & Metacarcinus magister & Predator \\
\hline Willipa Bay, Washington; NE Pacific & Dungeness crab & Metacarcinus magister & Behaviour \\
\hline Humbolt Bay, California; NE Pacific & Dungeness crab & Metacarcinus magister & Prey \\
\hline Gray's Harbor, Washington; NE Pacific & Dungeness crab & Metacarcinus magister & Predator \\
\hline Florida Bay, Florida; NW Atlantic & Caribbean spiny lobster & Panulirus argus & Prey \\
\hline $\begin{array}{l}\text { Florida Keys National Marine Sanctuary, Florida; } \\
\text { NW Atlantic }\end{array}$ & Caribbean spiny lobster & Panulirus argus & Prey \\
\hline Lee Stocking Island, Bahamas; NW Atlantic & Caribbean spiny lobster & Panulirus argus & Prey \\
\hline Florida Keys, Florida; NW Atlantic & Caribbean spiny lobster & Panulirus argus & Prey \\
\hline Western Australia; E Indian Ocean & Western rock lobster & Panulirus cygnus & Predator \\
\hline Santa Catalina Island, California; NE Pacific & Spiny lobster & Panulirus interruptus & Predator \\
\hline Channel Islands National Park, California; NE Pacific & Spiny lobster & Panulirus interruptus & Trophic cascade \\
\hline Santa Catalina Island, California; NE Pacific & Spiny lobster & Panulirus interruptus & Keystone predator \\
\hline Northwestern Hawaiian Islands; NE Pacific & Spiny lobster & Panulirus marginatus & Prey \\
\hline Barents Sea, Arctic Ocean & Red king crab & Paralithodes camtschaticus & Predator \\
\hline Kodiak Island, Alaska; NE Pacific & Red king crab & Paralithodes camtschaticus & Predator \\
\hline Barents Sea, Arctic Ocean & $\begin{array}{l}\text { Red king crab, } \\
\text { Northern stone crab }\end{array}$ & $\begin{array}{l}\text { Paralithodes camtschaticus, } \\
\text { Lithodes maia }\end{array}$ & Host \\
\hline
\end{tabular}


Table 1 (continued)

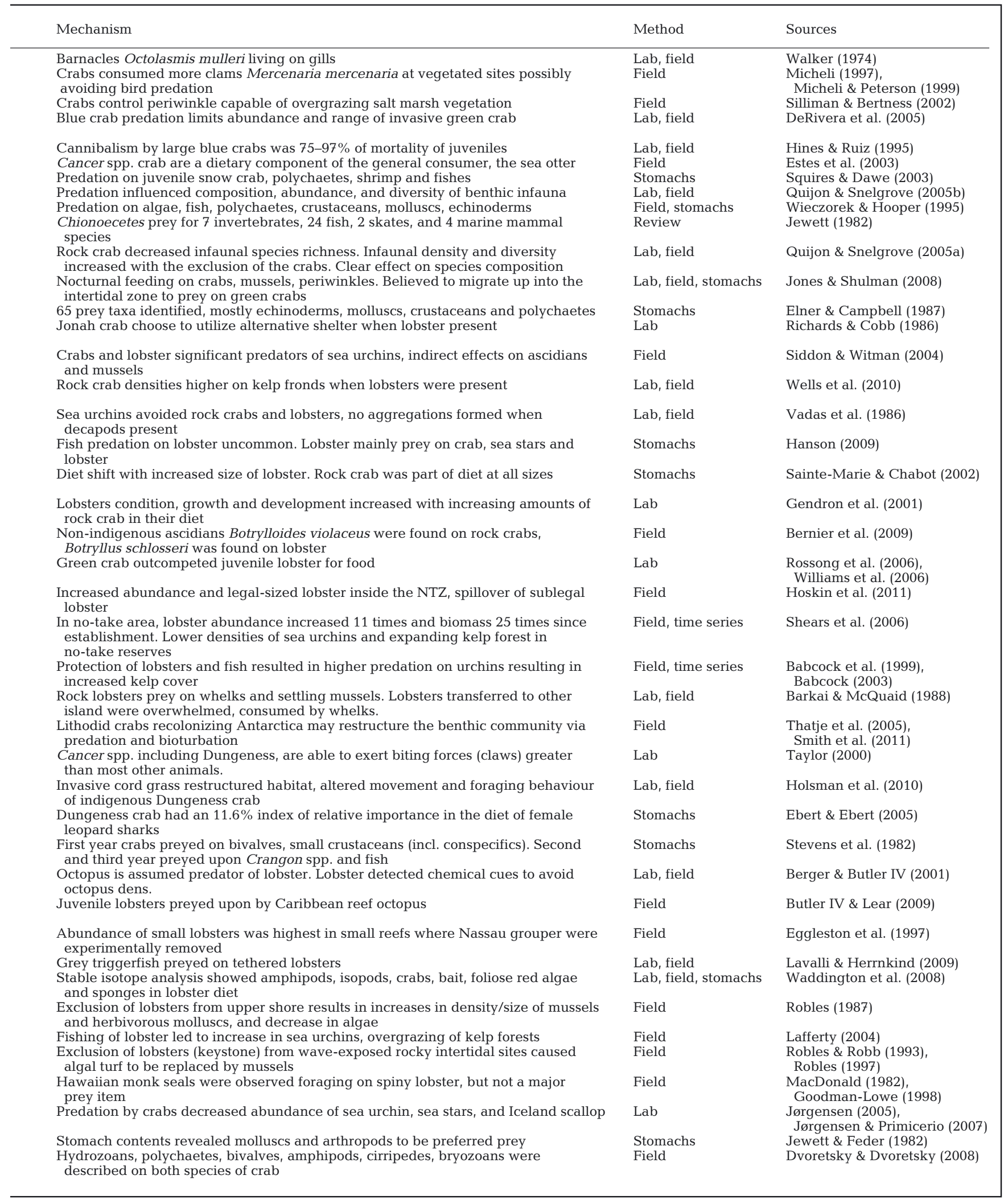


Avian predators such as the herring gull Larus agentatus and ring-billed gull $L$. delawarensis commonly feed on crabs, e.g. green or rock crabs (e.g. Dumas \& Witman 1993); likewise herons were observed to prey on blue crabs (Micheli 1997). Marine mammals, for example the Hawaiian monk seal Monachus schauinslandi, occasionally feed on various crustaceans including spiny lobsters $P$. marginatus (MacDonald 1982, Goodman-Lowe 1998). Decapods have not been identified as a major dietary component of seals or sea lions (Goodman-Lowe 1998, Beck et al. 2007, Boudreau \& Worm 2010). Similarly, Cancer spp. crabs are found in the diet of sea otters Enhydra lutris in the Pacific (Estes et al. 2003).

Of course most decapod species have multiple predators across their life cycle. Crabs of the genus Chionoecetes, for example, are known to be consumed by at least 7 species of invertebrates (including conspecifics, red king crab, and the sea star Asterias amurensis), 24 species of bony fish, 2 species of skate and 4 species of marine mammals. Most of these interactions were reported from the North Pacific, with the exception of predation by Atlantic cod on C. opilio (as well as cannibalism in C. opilio) in the Gulf of St. Lawrence (Jewett 1982 and references therein). In the northwest Gulf of St. Lawrence, SCUBA divers observed 2 incidences of $C$. opilio males holding dead, recently moulted mature females that were being consumed by whelks Buccinum undatum. Additional dead females and immature female exuviae were observed being consumed by lysianassoid amphipods (Sainte-Marie \& Hazel 1992).

Likewise, a number of bony fish and elasmobranchs prey on American lobster, Cancer spp., snow crab, and blue crab, at varying rates (e.g. Moss 1972, Robichaud et al. 1991, Rountree \& Able 1996, Steneck 1997, Boudreau \& Worm 2010, Boudreau et al. 2011). Some predators may be more important than others; in the soft substrates of the Southern Gulf of St. Lawrence, the shorthorn sculpin Myoxocephalus scorpius was the only demersal fish to consume large amounts of American lobsters $(2.6 \%$ frequency of occurrence, $28.9 \%$ biomass). Small amounts of lobster larvae were detected in pelagic fishes such as herring Clupea harengus, American shad Alosa sapidissima, and rainbow smelt Osmerus mordax; amounts were roughly proportional to their availability in the water column, suggesting random uptake of lobster larvae while filter-feeding zooplankton (Hanson 2009).

Predation risk is often increased at the post-settlement stage, when pelagic larvae recruit to benthic habitats. Substrate choice can have strong effects on species vulnerabilities to predation at this stage. For example, rock crabs settled at higher densities than lobster and were less selective of substrate, as they were found on both cobble and sandy substrate, whereas lobster clearly preferred cobble (Palma et al. 1998, 1999). Densities of post-settlement rock crabs, but not lobsters, increased in predator exclusion experiments (Palma et al. 1998, 1999).

In studies of spiny lobsters, early benthic phase individuals were vulnerable to predation and suffered high mortality from fishes and motile invertebrates (crabs and octopus) (Butler et al. 2006). Experiments confirmed that the abundances of juvenile lobster Panulirus argus increased on artificial patch reefs from which groupers Epinephelus striatus were removed (Eggleston et al. 1997). One interesting study documented that rock lobster Jasus lalandii could be overwhelmed and ingested by whelks Burnupena spp., reversing the typical predator-prey relationship between these 2 species (Barkai \& McQuaid 1988). Another demonstrated that Dungeness crab feeding switched from fish to crustaceans in the late spring, specifically preying upon the newly settled first instar conspecifics (Stevens et al. 1982).

We conclude that decapods form a supplementary food source for a wide variety of predators, ranging from gastropods to mammals, but that most species appear to be used opportunistically. There is little evidence that any predator species largely depends on the mega-crustaceans in their diet, with the exception of decapods preying on each other, which will be explored in the following section.

\section{Mega-decapods as predators}

Lobsters and crabs are often assumed to be detritivores and scavengers, yet in reality they exhibit a wide range of feeding strategies and behaviours. In fact, all species considered in this study actively prey on a variety of benthic invertebrates. Most studies have found that they are generalists that feed at more than one trophic level (omnivory), with preferences of particular prey species dependent on the area in which they are foraging (e.g. Jewett \& Feder 1982, Wieczorek \& Hooper 1995, Squires \& Dawe 2003) Their diet may include gastropods, bivalves, chitons, crustaceans, sea urchins, sea stars, polychaetes, algae and occasionally, fish (e.g. Jewett \& Feder 1982, Stevens et al. 1982, Elner \& Campbell 1987, Lawton 1987, Robles 1987, Wieczorek \& Hoo- 
per 1995, Cox et al. 1997, Squires \& Dawe 2003, Hanson 2009). Other decapods and even conspecifics are also consumed, including their moulted exoskeletons (e.g. Jewett 1982, Stevens et al. 1982, Elner \& Campbell 1987, Wieczorek \& Hooper 1995, Hanson 2009). Prey size tends to increase, and species preferences change with the size of the animal (e.g. Stevens et al. 1982, Robles et al. 1990, SainteMarie \& Chabot 2002, Squires \& Dawe 2003, Hanson 2009), likely reflecting their changing ability to manipulate larger and better defended organisms as they grow. Large decapods can often overpower the defenses of their prey, for example by crushing mussel shells (Robles et al. 1990). Decapods often have prey species in common with other invertebrates and fish (e.g. Robles 1987). There is a large body of literature documenting the range of diet items consumed by crabs and lobsters (Table 1), but much less is known about their effects on prey populations and communities.

The sympatric American lobster and rock crab are often studied in comparison. Rock crab consistently emerges in the literature as the lobster's preferred prey. Additionally, rock crab are also important to the somatic and gonadal growth of the American lobster (Gendron et al. 2001). This important dietary component for lobster is consistent and evident throughout its ontogenesis, but the contribution of crab, as well as their average size, increase with the size of the lobster (from $7 \%$ of stomach volume contents for the smallest lobster to $53 \%$ for the largest; Sainte-Marie \& Chabot 2002).

While American lobster and rock crab are typically found in highly structured hard-bottom habitats, they are also present in regions characterized by soft substrates, such as the southern Gulf of St. Lawrence (SGSL), NW Atlantic. In the SGSL, rock crab were an important diet item in the stomachs of lobsters $>40 \mathrm{~mm}$ CL (45 to $68 \%$ of prey biomass, $30 \%$ moulted carapaces, according to Hanson 2009). Additional prey items were small sea stars Asterias vulgaris (3.8$10.5 \%$ prey biomass) and lobsters $(0.7-12.9 \%$ of prey biomass, $70 \%$ were moulted carapaces) with molluscs, polychaetes and fish remains (cunner Tautogolabrus adspersus, three-spined stickleback Gasterosteus aculeatus, and herring) not exceeding $7.5 \%$ of the prey biomass (Hanson 2009).

Rock crab themselves were suggested to play an important role in structuring benthic communities, by influencing species composition and abundance, for example in Bonne Bay, Newfoundland (Quijon \& Snelgrove 2005a,b). Both rock and snow crab were reported to be the most abundant and frequently en- countered predators in Bonne Bay. When the crabs were experimentally excluded from the benthos, the polychaete Pholoe tecta and the clam Macoma calcarea came to dominate the benthic infauna, resulting in increased species richness overall (Quijon \& Snelgrove 2005a). Hence, crab fisheries may have indirect effects on benthic community structure (abundance, composition and diversity) by reducing crab predation on infauna (Quijon \& Snelgrove 2005a,b).

Decapods are often effective predators utilizing a variety of behavioural strategies. For example, in Southern California, spiny lobsters Panulirus interruptus like most decapods are intolerant to exposure, and hence forage on intertidal mussels Mytilus spp. on the evening high tide (Robles et al. 1990). There were shore-level differences in the mussels described in the study, with low-shore mussels having thinner shells than those in the upper zone. Large lobsters were observed to use trial and error to kill lower shore mussels before the thicker-shelled forms (Robles et al. 1990). When spiny lobsters were experimentally excluded from the upper shore, a significant increase in the density and size of mussels and herbivorous molluscs was observed, which indirectly decreased understory algal cover (Fig. 1A-C) (Robles 1987). Hence, lobster predation on mussels had multiple direct and indirect effects on this intertidal ecosystem.

Occasionally, decapod predators have been suggested to be keystone species (Table 1, Fig. 1) sensu Power et al. (1996), i.e. having a strong impact on the community, which is disproportionally large relative to their abundance. In the NW Atlantic, blue crabs were described as the keystone predators in salt marshes by being responsible for the regulation of marsh grass cover through a 3-level trophic cascade (Silliman \& Bertness 2002). Prior to this study, salt marshes had been mostly described as bottom-up regulated systems driven by nutrient inputs (e.g. Valiela \& Teal 1979), however a series of field experiments provided evidence that salt marshes may also be controlled by consumers. Blue crabs preyed on the herbivorous periwinkle Littoraria irrorata preventing it from decimating marsh grass Spartina spp., which would convert the complex habitat to mudflats (Fig. 1D-F). Using a variety of experimental methods, this cascade was found to occur when the periwinkle was at moderate to high densities. Based on these experimental findings, overfishing of blue crab was proposed as a possible mechanism contributing to the massive die-off of salt marshes in the southeast USA (Silliman \& Bertness 2002).

Similar drastic effects were observed at waveexposed rocky intertidal sites along Santa Catalina 

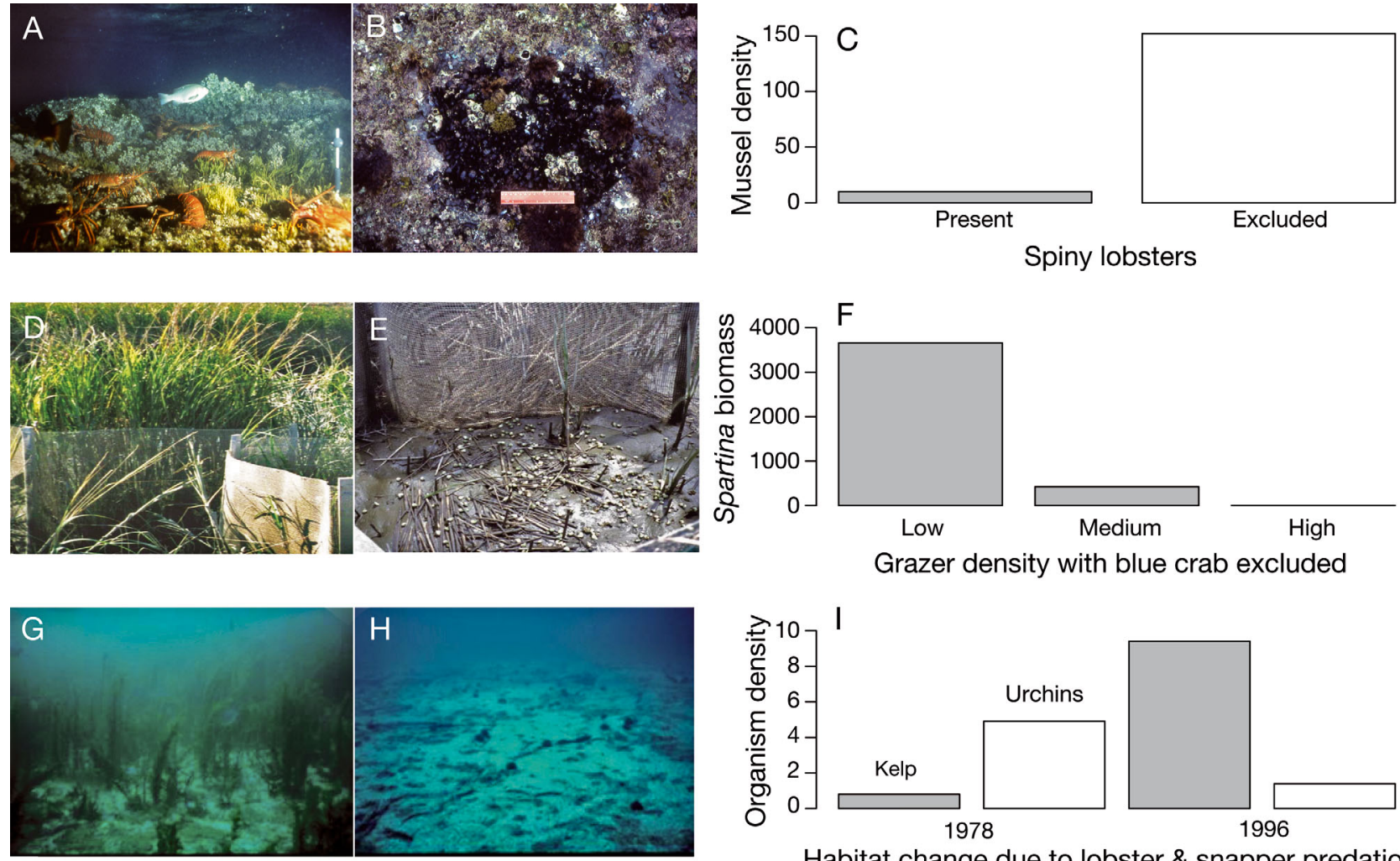

Habitat change due to lobster \& snapper predation

Fig. 1. Case studies exemplifying strong ecosystem effects of large decapods. Images: effects of decapod presence (left column) versus absence (right column). (A) Spiny lobster Panulirus interruptus preying on mussels in the wave-exposed rocky intertidal in California. (B) Exclusion of lobster caused algal turf to be replaced by mussels. (C) Mean number of mussels per $230 \mathrm{~cm}^{2}$ sampled after $10 \mathrm{mo}$, where lobsters were present (shaded) or excluded (open) (after Robles \& Robb 1993, Robles et al. 2001). (D) Spartina marsh grass in the tall zone with blue crab Callinectes sapidus predators excluded and low densities of grazing Littoraria irrorata versus (E) high densities of the same species in the same zone. (F) Spartina biomass ( $\mathrm{g}$ dry wt $\mathrm{m}^{-2}$ ) in the tall marsh zone after 8 mo of blue crab exclusion, in relation to Littoraria density (after Silliman \& Bertness 2002). (G) Lush kelp habitat resulting from the recovery of spiny lobster Jasus edswardii and snapper Pagurus auratus populations in Leigh Marine Reserve, New Zealand. (H) Urchin barrens, dominated by the sea urchin Evechinus chloroticus at the same site prior to establishment of the reserve. (I) Habitat shift at Leigh from 1978 to 1996 with kelp (shaded bars) and urchin (open) densities in numbers $\mathrm{m}^{-2}$ (after Babcock et al. 1999, Babcock 2003)

Island, California, where the exclusion of spiny lobsters Panulirus interruptus resulted in the complete and persistent replacement of a red algal turf by mussel Mytilus spp. beds; an example of keystone predation (Fig. 1A-C). At wave-protected sites, however, the lobsters were foraging on mussels jointly with carnivorous fishes and whelks; this was called diffuse predation (Robles \& Robb 1993). Notably, at wave-protected sites, the lobster and fish removals produced significant community changes only in combination with whelk removals (Robles \& Robb 1993).

American lobsters were also long believed to be a keystone predator of NW Atlantic subtidal kelp forests (Elner \& Vadas 1990). Specifically, it was hypothesized that lobsters controlled sea urchin pop- ulations through predation, and in turn prevented the destructive grazing of kelp forests by urchins, which commonly results in so-called 'urchin barrens' devoid of frondose macroalgae (Fig. 1G-I). However, Elner \& Campbell (1987) observed that lobster in both macroalgal and barren habitats did not preferentially prey on sea urchins. Their rank in the diet of lobster was variable and always surpassed by mussels. These observations did not support the hypothesis that lobster predation regulates sea urchins and indirectly maintains macroalgal habitats (Elner \& Campbell 1987). A subsequent extensive review on the topic found that there was a general lack of experimental testing and that contradictory evidence (e.g. lobster preferring crab to sea urchins) was discounted without explanation in the available litera- 
ture. Since then the attention has shifted from lobsters to large crabs, which may be able to control sea urchin densities at the juvenile stage, which would make them an effective top predator in the Gulf of Maine (GOM) ecosystem (reviewed by Steneck et al. 2004).

The diet of most large decapods appears to be mostly, but not exclusively carnivorous, with heavy emphasis on crustaceans or molluscs. Panulirus interruptus from the intertidal zone of Santa Catalina Island, California was found to have Mytilus spp. (88\% of the total sample of lobsters contained this prey item), other bivalves (96\%) and limpets (15\%) in their stomach contents (Robles 1987). Red king crab from inshore and offshore habitats around Kodiak Island, Alaska, mostly fed on molluscs (bivalves, $31.3 \%$ wet wt), crustaceans (mainly barnacles, $31.4 \%$ ) and fish (12.7\%) (Jewett \& Feder 1982). For snow crab in Newfoundland, the most frequently occurring prey items were polychaetes (81-90\%) and bivalves (43-48\%). With respect to prey biomass, however, shrimp (22-65\%) and fish (capelin Mallotus villosus, Atlantic spiny lumpsucker Eumicrotremus spinosus, redfish Sebastes spp.; 5-35\%) were more important. Crabs, mostly small Chionoecetes opilio, were also frequently consumed (Squires \& Dawe 2003). In Bonne Bay, Newfoundland, large crabs were more likely to scavenge on dead fish (e.g. discarded bait) and smaller crabs more likely to ingest shrimp (Wieczorek \& Hooper 1995). The most important prey item in the diet of Dungeness crab in Gray's Harbor, Washington, was the shrimp Crangon spp.; however, first year (small) Metacarcinus magister preferred small bivalves or small crustaceans, including conspecifics (Stevens et al. 1982). Of note in this study was the importance of teleost fish to the diet of second and third year crab.

Stable isotope analysis has been used to determine the trophic position of decapods (e.g. Grabowski et al. 2009). An analysis of western rock lobsters Panulirus cygus from the west coast of Australia revealed that they were highly omnivorous, with diets consisting of amphipods, isopods, crabs, bait, foliose red algae and sponges (Waddington et al. 2008). The proportional contributions differed widely among locations, but bait $(4-79 \%)$, crabs $(0-76 \%)$ and amphipods or isopods $(0-54 \%)$ were important in most cases while algae and sponges were less important. On average lobsters occupied the trophic position of a first-order predator. Lobsters in the deep coastal zone (35 to $60 \mathrm{~m}$ ) were primarily carnivorous and this did not vary with sex, size or location (Waddington et al. 2008).

We conclude that the decapod species reviewed here actively prey on a range of organisms in a variety of benthic habitats, ranging from the intertidal zone (i.e. Robles \& Robb 1993) to deep waters (i.e. Smith et al. 2012). Their preferred prey items appear to be other decapods and molluscs, namely mussels. The wider impacts of their foraging can be substantial (for example keystone predation by spiny lobster and blue crab; Figs. 1 \& 2). Experiments where decapod predators were excluded consistently reported an increase in benthic infaunal or epifaunal density, changes in species composition, and sometimes cascading effects affecting various epifauna and vegetation. Collectively, the available evidence suggests that large decapods can play important roles in structuring benthic communities; however it is not clear how general these roles are and to which extent they can be assumed across species (e.g. American lobster; Elner \& Vadas 1990).

\section{Non-consumptive interactions}

Decapods are not only involved in predator-prey interactions, but also compete with other species for food and habitat, as well as providing and altering habitat themselves. These non-consumptive interactions have received somewhat less attention than predatory ones, but may nevertheless represent an important aspect of decapod ecology.

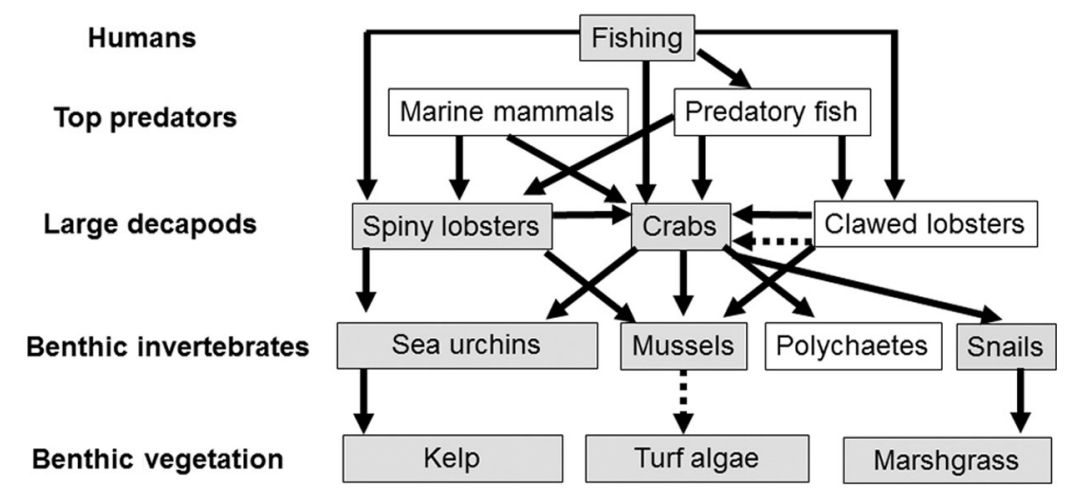

Fig. 2. Conceptual synthesis. Major documented ecosystem interactions of large decapods include predatory (solid arrows) and competitive (dotted arrows) interactions. Cannibalistic interactions occur in crabs and lobster, but are not shown here. Grey: species that are strongly implicated in trophic cascades. Note this represents a simplified scheme; other interactions may well occur depending on species diets and other ecological traits in particular regions 
Interference competition. Negative, direct interactions between organisms trying to access the same resource are called interference competition. In decapods, agonistic displays, visual displays or combat may play a role during disputes over limited resources such as food or shelter (Rossong et al. 2006), depending on the species in question, and its life stage. For example, American lobsters use agonistic displays first, while green crabs tend to go immediately to combat (Sneddon et al. 1997a,b). Green crabs are able to outcompete and ingest juvenile lobsters (Rossong et al. 2006), and compete with sub-adult lobsters for resources (Williams et al. 2006); however, they are often preferred food for adult lobster (Jones \& Shulman 2008).

Competition for habitat. To avoid predation, many decapods are nocturnal and seek protective shelter during the day. The American lobster is sympatric with 2 species of Cancer crab, which compete for suitable shelter, but are often displaced by lobster when shelter is limited (Richards \& Cobb 1986). Crabs, however, were more flexible in their requirements for shelter than lobster and had an ability to rapidly burrow and use a wider variety of crevice configurations in the field. Shelter appeared to be more important to lobster survival than to crab, implying that habitat limitation could be detrimental to lobster by exposing them to increased predation mortality (Richards \& Cobb 1986, Wells et al. 2010). However, shelter does become relatively less important to lobster as their size increases, and relative predation risk decreases (Wahle 1992). Recently, American lobster have been observed more frequently in predation-prone habitats such as soft-bottoms where effective shelter is rare (Tremblay \& Smith 2001, Geraldi et al. 2009), this might signal a habitat expansion due to lower abundances of predatory groundfish (Boudreau \& Worm 2010). Also, lobsters have a limited capacity for creating shelter in soft sediments by burrowing bowl-like depressions (Tremblay \& Smith 2001).

Habitat provision. Most decapods do not only use habitat, but can provide habitat for other invertebrates, for example barnacles Balanus spp., polychaetes, bivalves, crustaceans and gastropods that may settle on them (e.g. Bernier et al. 2009, Dvoretsky \& Dvoretsky 2009). For example, red king and snow crabs carry sea leach adults Johanssonia arctica and their egg cases in the North Pacific and Barents Sea (Dvoretsky \& Dvoretsky 2008), and barnacles Octolasmis mulleri have been found growing on the gills of blue crab in North Carolina (Walker 1974). The high mobility of many mega-decapods is beneficial to suspension feeders, and also to mobile epifauna, as they gain protection in addition to access to scraps from feeding. This shelter is often only temporary as decapods moult their exoskeleton, hence most suitable for fast-growing, short-lived epifaunal species. However, as the animal ages, moulting frequency slows, often reaching a terminal moult, for example in snow crab (e.g. Sainte-Marie et al. 1995, Choi \& Zisserson 2008) and female blue crab (e.g. Haefner \& Shuster 1964). These species can gradually become debilitated under an increasing load of epizoites (Walker 1974). Brooding female decapods may also provide food in terms of eggs to nemerteans (e.g. Wickham 1986, Wickham \& Kuris 1988) and amphipods (e.g. Dvoretsky \& Dvoretsky 2010) living on them. Decapods with epibionts can also act as vectors for the spread of invasive species. For example, rock crab and American lobster were discovered to carry invasive tunicates (Botrylloides sp., Botryllus sp.) (Bernier et al. 2009).

\section{ANTHROPOGENIC FACTORS}

Fishing, marine protected areas, and species introductions may be changing the way large crustaceans are distributed and play out their ecosystem roles. We will examine each of these potential factors in detail.

\section{Commercial fishing}

Decapods have become increasingly important to commercial fisheries, often as a result of declining groundfisheries (e.g. Pauly et al. 1998, Worm \& Myers 2003, Anderson et al. 2008, 2011, Choi \& Zisserson 2008). Many invertebrate fisheries operate under scarce ecological and life-history information (e.g. natural mortality rates, nursery habitats) and without having proper stock assessments conducted (Anderson et al. 2008). Fisheries by their nature remove a certain proportion of the population and in absence of appropriate biological reference points there is a risk of overexploitation (Jennings \& Kaiser 1998, Worm et al. 2009). This is particularly true for some highly valued invertebrate fisheries, where particular populations have declined abruptly and shown slow recovery (e.g. Alaskan red king crab; Orensanz et al. 1998). However, there are well-known exceptions to this pattern, for example the American lobster fishery in the NW Atlantic has exhibited an increase in abundance and landings that began around 1980 and po- 
tentially replaced large fish as the dominant predator in the ecosystem, which may have in turn influenced various prey species (Pezzack 1992, ASMFC 2006, DFO 2006, Steneck 2006, Boudreau \& Worm 2010, Steneck et al. 2011). Yet, this lobster population is not without potential threats, as the nominal fishing effort has been increasing (Gendron \& Archambault 1997, Gendron et al. 2000, Pezzack et al. 2001, DFO 2006), and there has been a trend of fishing larger lobster in deeper water. Whether these individuals are essential broodstock and how their removal will affect recruitment, and hence the future of the population, has yet to be determined (DFO 2006, Boudreau \& Worm 2010).

In addition to these population-level impacts, fishing operations may also affect species interactions (Estes et al. 2011, Steneck et al. 2011) by removing predators of decapods (e.g. Atlantic cod) or prey (e.g. rock crab) species, and by altering habitat (e.g. scallop dredges, Kaiser et al. 2006). These interactions can have important implications for multispecies management. For example, rock crab is important to the diet of American lobster (e.g. Sainte-Marie \& Chabot 2002). Given that lobster has a far higher commercial value, the fishery for rock crab should be managed conservatively in order to leave sufficient high-quality prey for lobsters (e.g. Gendron et al. 2001). It is not clear, however, how these findings relate to other species; while studies on American lobster or snow crab often mention their interactions with sympatric species of crab, such associations were largely absent from studies on other species reviewed here.

Another potentially important interaction between decapods and fishers are mediated by bait inputs. There is some evidence that bait losses as well as discards have the potential to subsidize decapod populations, for example, in the GOM American lobster fishery (Saila et al. 2002, Grabowski et al. 2009) and the Western Australia rock lobster fishery (Waddington \& Meeuwig 2009). In Western Australia, stable isotope analysis and gut contents analysis indicated that bait inputs contributed between 30 and $80 \%$ of the diet of rock lobster Panulirus cygnus. However, the amount of bait available depends on the length of the fishing season (Waddington et al. 2008). In the Western GOM, year-round fishing and its bait inputs, may have significant effects on lobster (Saila et al. 2002, Grabowski et al. 2009), whereas this is probably not the case in the Eastern GOM, where the fishing season is limited to winter and bait inputs are considerably lower (Grabowski et al. 2009, Boudreau \& Worm 2010).
The long-term effects of decapods being fed large amounts of bait are unclear. There is some evidence that American lobsters in New Brunswick, where bait is available only in winter, outgrew those in Maine where bait is available year round (Grabowski et al. 2009). It is also possible that a diet that largely relies on herring bait affects the physiological condition of those animals (Myers \& Tlusty 2009). Finally, whether an increase of bait in lobster diets has resulted in a reduction of predation rates by lobsters on their regular prey species, has yet to be tested.

In conclusion, fisheries may have a range of effects on the ecosystem. Removal of groundfish or other decapod predators can lead to population increases and shifts in trophic structure. Additionally, fishing may decrease the abundance of key prey items (e.g. rock crab for American lobster) or supplement decapod diets through bait.

\section{Conservation and protected areas}

The potentially large effects of fishing on decapods often become most apparent when this influence is removed, in what Castilla (1999) has termed a 'human exclusion experiment'. Marine reserves where fishing is excluded can be valuable in this regard, in testing ecosystem level effects of fished species at ecologically relevant scales (Shears \& Babcock 2002). Reserves have been shown to successfully protect and increase spiny lobster populations (e.g. Kelly et al. 2000), which had strong cascading effects throughout the ecosystem (Fig. 1G-I). In northeastern New Zealand, Taharanui Marine Park (established 1981, implemented 1983) and Leigh Marine Reserve (established in 1975) are no-take reserves, whereas Mimiwhangata Marine Park (established 1984, commercial fishing phased out by 1993) allows recreational fishing. Several studies documented the development of benthic communities inside and outside these reserve sites. In the Leigh Marine Reserve and Taharanui Marine Park, trends post-reserve revealed that the most common demersal predatory fish, the Cockney snapper Pagrus auratus, was 5.8 and 8.7 times more abundant and considerably larger inside these 2 reserves when compared with adjacent unprotected areas. The spiny lobster Jasus edwardsii showed similar trends (1.6 to 3.7 times more abundant, as well as increased mean size). In one of the reserves, densities of the dominant sea urchin Evechinus chloroticus (not of significant commercial value) had declined from 4.9 to $1.4 \mathrm{~m}^{-2}$ since 1978. Consequently, kelp forests 
were less heavily grazed and more extensive in cover in 1998 than they were at the time of reserve creation. Macroalgal primary productivity was estimated to be $\sim 58 \%$ greater within the Leigh reserve in 1998 than it was in 1980. Urchin-dominated barrens occupied only $14 \%$ of available reef substratum in reserves as opposed to $40 \%$ in unprotected areas (Fig. 1G-I). These changes in community structure, which have persisted since at least 1994, suggest a trophic cascade from lobsters and fish to urchins and kelp that led to increased primary and secondary productivity in marine reserves as a consequence of protection (Babcock et al. 1999).

Interactions between lobsters and sea urchins continue to be of importance. In the no-take marine parks and at sites outside the reserves mentioned above, field experiments during 1998-99 revealed that lobsters preyed on a range of sea urchins. Tethering experiments suggested that lobster were responsible for at least $45 \%$ of predation on urchins in the reserve sites; the rest was attributed to snapper and potentially to several slow-moving predators such as the sea star Coscinasterias muricata, or the gastropod Charonia lampax. Predation on urchins was significantly (6.9 times) higher inside the reserve than outside. Consequently, the density of adult sea urchins grazing on barrens within reserve sites was significantly lower than outside. Experimental removal of sea urchins $>12$ mo led to a change from crustose coralline algae to macroalgal canopies that mimic habitats now commonly found in the reserves (Shears \& Babcock 2002). Such changes in habitat are believed to affect a host of other species. For example, in the Leigh Marine Reserve, lower density of the limpet Cellana stellifera and higher densities of the turbinid gastropod Cookia sulcata are thought to be responses to changes in the habitat structure indirectly resulting from the increased density of urchin predators (Shears \& Babcock 2003).

Not just commercial exploitation, but limited recreational fishing may also affect these interaction chains. In Taharanui and Mimiwhangata Marine Park lobster densities were similar prior to the creation of the parks. After full protection in Taharanui, the abundance of legal-sized lobster increased 11fold and biomass increased 25-fold. Mimiwhangata Park, in contrast, allowed recreational fishing and showed no significant change in the abundance or biomass of legal size lobsters, nor any spatial difference to fully fished areas adjacent to the park. Likewise, other urchin predators have not recovered following partial protection in Mimiwhangata (Shears et al. 2006). Consequently, kelp forest habitats that dominated on shallow reefs up until the 1950s have been replaced by urchin barrens that have persisted at least since the 1970s (Kerr \& Grace 2005).

In a similar example from Southern California, large spiny lobsters Panulirus interruptus prey on the purple Strongylocentrotus purpuratus (Tegner \& Levin 1983) and red sea urchins $S$. franciscanus (Tegner \& Dayton 1981). By contrast, in cold water sites such as Torch Bay, Alaska, where lobsters are absent, the predatory seastar Pycnopodia helianthoides is an important urchin predator (Duggins 1983). In southern California, a large fish, the sheepshead Semicossyphus pulcher, can also reduce urchin densities (Cowen 1983) and in combination with P. interruptus, structure the sea urchins' size frequency distributions (Tegner \& Dayton 1981). Sampling in and around the Anacapa marine reserve in Channel Islands National Park, California, revealed that where the main predators on urchins were fished, urchin populations increased to such an extent that they overgrazed algae and starvation eventually limited urchin population growth (Lafferty 2004). Individual growth rates were also reduced and epidemics were 4 times more frequent outside the reserve than inside. However, the availability of food and temperature did not appear to influence disease. It was inferred that overfishing the spiny lobster, and therefore releasing urchins from predation, could in turn promote disease transmission as urchin density increased (Lafferty 2004).

In the Atlantic Ocean, one short-term study of American lobsters in a reserve exists from Bonavista Bay, Newfoundland (Rowe 2002). Increases in body size and density were documented after $3 \mathrm{yr}$ of protection. There was evidence to suggest that the creation of these no-take reserves would benefit fisheries by increasing lobster survival (Rowe 2001, 2002); however, no wider ecosystem effects were examined. In the northeast Atlantic, European lobster abundance and size rapidly increased after the establishment of the UK's first no-take zone (NTZ) in 2003. Evidence also indicated a 'spillover' into areas adjacent to the NTZ where an increase of sub-legal lobsters was observed (Hoskin et al. 2011). In contrast, European lobster tagged in a Skagerrak coast reserve (Norway) were observed to remain in the reserve or near the boundary (Moland et al. 2011).

We conclude that it is possible to observe strong species interactions and trophic cascades due to the recovery of spiny lobsters, as well as other predators in some marine reserves. Urchins seem to be particularly important in mediating these ecosystem-wide effects. Again, it is unclear whether and how these 
results transfer to other species, such as large crabs and clawed lobsters. Marine reserves, especially when replicated at different sites and during different time periods, create an excellent opportunity to study the potential direct and indirect effects of fishing on benthic communities.

\section{Decapod introductions and invasions}

Introductions and invasions lead to the establishment of a species in a habitat where it was not formerly found. As such, these events provide quasi-experimental context in which to examine the ecosystem role of particular species. Marine invasive species have been described as important drivers of ecological change. They are often viewed as being irreversible and their impacts can lead to changes in habitat and displacement of native species via predatory or competitive interactions (Bax et al. 2003). However, it is often quite difficult to quantify these ecosystem consequences in the marine environment.

Once a non-indigenous organism has been introduced into a region, indigenous species may indirectly facilitate its spread. For example, by feeding on mussels, Jonah crabs Cancer borealis had a positive indirect effect on the abundance of an introduced ascidian Diplosoma sp., by facilitating bare substrate for settlement and successful colonization of the invader (Siddon \& Witman 2004). American lobster, when present, reduced the foraging effectiveness of the crabs on mussels. The authors were concerned that the harvesting of lobsters may lead to increased crab predation on mussels and in turn, an increase in Diplosoma sp. cover in the GOM (Siddon \&Witman 2004).

One important case study concerns red king crab, which was introduced to the Barents Sea by the former Soviet Union from 1961 to 1969 to establish a commercial fishery. In 1974, a first berried female was found; by 1976, there were at least 100 records, and the introduction was considered a success (Orlov \& Ivanov 1978). This population is now believed to be actively invading coastal waters through migration of mature crabs and passive dispersal of larvae (Pedersen et al. 2006). Red king crabs are currently abundant along the Finmark coast of Northern Norway with an estimated population of 3.5 million crabs $>70 \mathrm{~mm}$ CL in 2003 (Hjelset et al. 2003).

Like most mega-decapods, adult red king crabs are opportunistic omnivores (Cunningham 1969). There is great concern that these crabs will decimate the native Iceland scallop Chlamys islandica, a slowgrowing, commercially important species with a depth distribution that overlaps with the invasive king crab population. Laboratory studies suggested that even small king crabs would have an impact on the scallop community by removing sea urchins, sea stars, and scallops (Jørgensen 2005). Scallops made up 73 to $97 \%$ of the prey weight (g) foraged by the crabs. The benthic community impacts associated with the migratory medium-sized to large crabs may extend to other species as well; for example, horse mussels and common whelks were crushed and consumed by these individuals. This invasion is progressing rapidly: in 2001, a non-invaded control bed was selected for long term monitoring in Porsanger fjord, Norway. Invasion was expected within 5 to $8 \mathrm{yr}$ (Jørgensen 2005); however, the first red king crab was already recorded 4 yr later (Jørgensen \& Primicero 2007).

In addition to intentional introductions, the Arctic and Antarctic are now being exposed to species invasions from lower latitudes due to climate change. For example, king crabs (Lithodes spp., Paralomis spp., Neolithodes spp.) have recently been recorded in the Antarctic Ocean for the first time since an extinction event in the Miocene ( 15 million yr BP) that is thought to have occurred due to Antarctic cooling. Migration from the deep sea is the most likely mechanism for recolonization (Thatje et al. 2005). These species also have larvae that are well-adapted to low temperatures and low levels of plankton productivity (Anger et al. 2003). As king crabs re-establish, they may impact the rich fauna of large amphipods and isopods found in this region and could further affect benthic communities by consuming echinoderms and crustaceans (Thatje et al. 2005) and altering sediments through locomotive and feeding activities (Smith et al. 2012).

There could also be other unintended impacts from introduced species on indigenous decapods. For example, in the north Pacific (Washington, USA), the introduced Atlantic smooth cordgrass Spartina alterniflora has transformed previously unstructured habitats to highly structured marsh meadows. This ecosystem transition has altered the movement and foraging behaviour of the Dungeness crab and increased its risk of being trapped in marsh grass and exposed at low tide (Holsman et al. 2010).

We conclude that mega-decapods, once introduced to a new region, can become successfully established and have the potential to dramatically alter the benthic community through predation. They are vulnerable to the establishment of non- 
indigenous vegetation, which can restructure their habitat. Additionally, indigenous mega-decapods may facilitate the dispersal of non-indigenous sessile organisms by providing habitat and also indirectly by preying upon bivalves resulting in bare substrate upon which other invasives may settle. As climate change continues to increase average ocean temperature, invasions may increase in frequency as species expand their distributions.

\section{DISCUSSION}

This review indicates that large decapods play an important role in benthic communities, ranging from intertidal to deep waters (Table 1). These effects are mediated by the following mechanisms (Fig. 2): (1) Decapods are prey for a large range of vertebrate (humans, marine mammals and fish) and invertebrate (mostly other decapods) predators; however, they did not appear to be a key dietary component for non-decapod species. (2) They are successful and versatile predators, preying at more than one trophic level, mostly on benthic invertebrates, but occasionally consuming algae or detritus. Some species, especially spiny lobsters and blue crabs, have demonstrated large effects on benthic community structure, either as keystone species or by inducing trophic cascades. (3) Decapods interact with the habitat and its inhabitants in a variety of ways, including providing habitat for smaller invertebrates, and competing for food and shelter.

For the species and ecosystems reviewed here, one of the most striking interactions was that of regulating trophic cascades (Fig. 1, grey boxes in Fig. 2). These trophic cascades took place in a variety of temperate habitats, from the rocky intertidal (Robles \& Robb 1993) to saltmarshes (Silliman \& Bertness 2002) and subtidal reefs (Babcock et al. 1999). In these cases, large decapods were essential in the maintenance of benthic vegetation (kelp forests, marsh grass, or turf algae), and therefore habitat complexity and productivity by regulating the grazing community (e.g. gastropods, sea urchins). Often predatory decapods were joined in this function by fish (Robles \& Robb 1993, Babcock et al. 1999) or whelks (e.g. Robles \& Robb 1993). Predatory interactions between spiny lobsters and crabs on sea urchins were demonstrated to be important; however, no such relationship has become evident for American (or European) lobsters. Instead, American lobster appear to prefer crabs in their diet, and it is possible that these observed differences could be due to their claws allowing them to be more effective at capturing and consuming mobile and well-defended prey. Exclusion experiments (e.g. Quijón \& Snelgrove 2005a,b) often supported the hypothesis of strong ecosystem effects of decapods on benthic fauna (molluscs, polychaetes), even if no trophic cascade was observed.

Decapods themselves may be commonly regulated in their abundance by predators (Fig. 2). Exclusion of fish predators allowed decapod populations to increase, for example in the case of Nassau grouper preying on juvenile Panulirus argus (Eggleston et al. 1997). A similar release from (mostly gadoid) fish predation has contributed to observed increases in the abundance of American lobster and snow crab in the NW Atlantic (e.g. Worm \& Myers 2003, Steneck et al. 2004, Frank et al. 2005, Zhang \& Chen 2007, Boudreau \& Worm 2010, Boudreau et al. 2011). This body of evidence adds to a growing concern that commercial fisheries have the potential to affect ecosystem function through the removal of certain predators (Fig. 2), influencing species interactions, and in some cases leading to cascading changes throughout the ecosystem (e.g. Dill et al. 2003, Baum \& Worm 2009, Estes et al. 2011).

It has become evident from the research reviewed here that decapods have evolved to become efficient predators of other shelled organisms (mostly bivalves, gastropods, echinoderms, and crustaceans) due largely to their uniquely strong claws (Taylor 2000). They prey on these items across a broad range of habitats and are capable of controlling strong space competitors, such as mussels, to maintain algal growth or mobile herbivores (sea urchins, snails) grazing on algae (kelp, sea grass, turf algae), with strong indirect effects on habitat structure and (likely) primary productivity (Figs. 1 \& 2). Furthermore, if teleost predators of decapods become overharvested, those decapods typically increase in abundance, and hence in their importance in the ecosystem, where they can become the dominant predator in some cases (Steneck et al. 2011).

While the focus of this review has been largely on predatory (top-down) species interactions, it is important to note that other mechanisms are also present in the ecosystem. Environmental variables, such as temperature and hydrodynamics (e.g. Higgins et al. 1997), and density-dependent mechanisms (e.g. Wahle 2003) are common bottom-up factors that explain changes in mega-decapod abundance. For example, Dungeness crab Metacarcinus magister exhibit cycles of recruitment linked to spring oceanographic conditions that influence currents and larval transport, directly affecting early life stages (Shanks 
\& Roegner 2007). Crab such as Chionoecetes opilio (Conan et al. 1996, Caddy et al. 2005) and Callinectes sapidus (Hines \& Ruiz 1995) display strong densitydependent population regulation (i.e. via cannibalism), which may partly explain observed population cycles. Thus, while the top-down mechanisms displayed in Figs. 1 \& 2 are undoubtedly important, other factors will come into play when considering decapods in a full ecosystem context.

Although the available evidence does suggest that large marine decapods play a role in structuring benthic communities, this literature review also exposed some clear knowledge gaps. For example, comprehensive long-term studies of benthic communities documenting changes in mobile and sedentary inand epi-fauna are scarce. It appears that most studies examine one particular interaction (e.g. decapods as predators) and rarely consider the species in a full ecosystem context. Recently fisheries scientists and managers have been considering ecosystem-based approaches that take into account trophic interactions and human as well as natural sources of mortality (e.g. Garcia et al. 2003). Towards this goal, scientists have been using sophisticated modeling techniques, such as multispecies virtual population analyses and mass-balance models (e.g. Walters et al. 1997, Hanson \& Chouinard 2002, Zhang \& Chen 2007). These models are parameterized using available dietary studies (such as those described in this paper) and population time series summarized for a given ecosystem (Walters et al. 1997, Hanson \& Chouinard 2002). These methods can be useful, for example, to examine the possible consequences of complex ecosystem shifts (e.g. for the GOM; Zhang \& Chen 2007), but cannot replace long-term empirical and experimental studies.

Long-term studies could be of great value for creating a baseline as fishing, climate change and other impacts continue to alter ocean ecosystems. A diverse range of other benthic community members such as fish, sea stars or even amphipods and isopods interact with mega-decapods. Thus, detailed time series of these species could be beneficial in understanding and predicting broader ecosystem change. Time series, however, cannot uncover mechanisms; hence detailed mechanistic studies are equally essential. For example, several predator exclusion experiments reviewed here provided valuable insights into the mechanisms by which large decapods affect community structure across a range of benthic habitats. Results from such experiments may also be used to parameterize ecosystem-based models. However, interactions with benthic fishes were not cov- ered in much detail in the literature and we suggest that this could be further examined.

Many of the factors and interactions examined in this paper are linked: consider for example the complex mechanisms of interference-competition (Rossong et al. 2006, Williams et al. 2006) and predation at different life stages between an indigenous commercially harvested decapod (American lobster) and non-indigenous competitors (green crab) and prey (Jones \& Shulman 2008). Such complexities highlight the fact that an ecosystem-based approach to understanding and managing these valuable resources would be informative.

As more decapod populations are of increasing socio-economic importance and continue to be harvested more widely (Anderson et al. 2011), it is important that we expand our knowledge of ecological interactions that affect the abundance of these species, their prey, and habitat. It is our hope that this knowledge may ultimately help managers maintain critical trophic interactions and prevent overexploitation in an ecosystem context.

Acknowledgements. We thank H. Lotze, S. Walde, J. Tremblay, T. Romanuk, and R. Wahle for helpful comments and discussions, and to R. Babcock, B. Silliman, and C. Robles, for contributing photos. Funding was provided by the National Sciences and Engineering Research Council, Ecosystem Studies of Subarctic Seas, and Dalhousie University.

\section{LITERATURE CITED}

Anderson SC, Lotze HK, Shackell NL (2008) Evaluating the knowledge base for expanding low-trophic-level fisheries in Atlantic Canada. Can J Fish Aquat Sci 65: 2553-2571

> Anderson SC, Flemming JM, Watson R, Lotze HK (2011) Rapid global expansion of invertebrate fisheries: trends, drivers, and ecosystem effects. PLoS ONE 6:e14735

Anger K, Thatje S, Lovrich G, Calcagno J (2003) Larval and early juvenile development of Paralomis granulosa reared at different temperatures: tolerance of cold and food limitation in a lithodid crab from high latitudes. Mar Ecol Prog Ser 253:243-251

ASMFC (Atlantic States Marine Fisheries Commission) (2006) American lobster assessment for peer review. Stock Assess Rep No. 06-03 (suppl), ASMFC, Washington, DC

Atema J, Cobb JS (1980) Social behavior. In: Cobb JS, Phillips BF (eds) The biology and management of lobsters, Vol 1: physiology and behavior. Academic Press, New York, NY, p 409-450

Atema J, Voight R (1995) Behavior and sensory biology. In: Factor JR (ed) The biology of the lobster, Homarus americanus. Academic Press, New York, NY, p 313-348

Babcock RC (2003) The New Zealand marine reserve experience: the science behind the politics. In: Hutchings $P$, Lunney D (eds) Conserving marine environments: out of sight, out of mind? R Zool Soc, Mosman New South 
Wales, p 108-119

Babcock RC, Kelly S, Shears NT, Walker JW, Willis TJ (1999) Changes in community structure in temperate marine reserves. Mar Ecol Prog Ser 189:125-134

Barkai A, McQuaid C (1988) Predator-prey role reversal in a marine benthic ecosystem. Science 242:62-64

Barshaw DE, Lavalli KL, Spanier E (2003) Offense versus defense: responses of three morphological types of lobster to predation. Mar Ecol Prog Ser 256:171-182

Baum JK, Worm B (2009) Cascading top-down effects of changing oceanic predator abundances. J Anim Ecol 78: 699-714

Bax N, Williamson A, Aguero M, Gonzalez E, Geeves W (2003) Marine invasive alien species: a threat to global biodiversity. Mar Policy 27:313-323

- Beck CA, Iverson SJ, Bowen WD, Blanchard W (2007) Sex differences in grey seal diet reflect seasonal variation in foraging behaviour and reproductive expenditure: evidence from quantitative fatty acid signature analysis. J Anim Ecol 76:490-502

> Berger DK, Butler MJ IV (2001) Octopuses influence den selection by juvenile Caribbean spiny lobster. Mar Freshw Res 52:1049-1053

Bernier R, Locke A, Hanson JM (2009) Lobsters and crabs as potential vectors for tunicate dispersal in the southern Gulf of St. Lawrence, Canada. Aquat Invasions 4: 105-110

Boudreau SA, Worm B (2010) Top-down control of lobster in the Gulf of Maine: insights from local ecological knowledge and research surveys. Mar Ecol Prog Ser 403: 181-191

Boudreau SA, Anderson SC, Worm B (2011) Top-down interactions and temperature control of snow crab abundance in the northwest Atlantic Ocean. Mar Ecol Prog Ser 429: 169-183

Butler MJ IV, Lear JA (2009) Habitat-based intraguild predation by Caribbean reef octopus Octopus briareus on juvenile Caribbean spiny lobster Panulirus argus. Mar Ecol Prog Ser 386:115-122

Butler MJ IV, Steneck RS, Herrnkind WF (2006) Juvenile and adult ecology. In: Phillips BF (ed) Lobsters: biology and management. Blackwell Scientific Press, Oxford, p 263-309

Caddy JF, Wade E, Surette T, Hebert M, Moriyasu M (2005) Using an empirical traffic light procedure for monitoring and forecasting in the Gulf of St. Lawrence fishery for the snow crab, Chionoecetes opilio. Fish Res 76:123-145

Castilla JC (1999) Coastal marine communities: trends and perspectives from human-exclusion experiments. Trends Ecol Evol 14:280-283

Choi JS, Zisserson BM (2008) An assessment of the snow crab resident on the Scotian Shelf in 2006, focusing upon CFA 4X. Can Sci Advis Sec Res, Doc 2008/003

Conan GY, Starr M, Comeau M, Therriault JC, Hernàndez FXM, Robichaud G (1996) Life history strategies, recruitment fluctuations, and management of the Bonne Bay Fjord Atlantic snow crab (Chionoecetes opilio). In: High latitude crabs: biology, management, and economics. Prog Rep 96-02, Alaska Sea Grant College, Anchorage AK, p 59-97

Cowen RK (1983) The effect of sheephead (Semicossyphus pulcher) predation on red sea urchin (Strongylocentrotus franciscanus) populations: an experimental analysis. Oecologia 58:249-255

Cox C, Hunt JH, Lyons WG, Davis GE (1997) Nocturnal foraging of the Caribbean spiny lobster (Panulirus argus) on offshore reefs of Florida, USA. Mar Freshw Res 48:
$671-679$

Cunningham DT (1969) A study of the food and feeding relationships of the Alaskan king crab Paralithodes camtschatica. MSc thesis, San Diego State College, CA

Cunningham CW, Blackstone NW, Buss LW (1992) Evolution of king crabs from hermit crab ancestors. Nature 355:539-542

> DeRivera CE, Ruiz GM, Hines AH, Jivoff P (2005) Biotic resistance to invasion: native predator limits abundance and distribution of an introduced crab. Ecology 86: 3364-3376

DFO (Department of Fisheries and Oceans Canada) (2006) Framework assessment for lobster (Homarus americanus) in lobster fishing area (LFA) 34. Can Sci Advis Sec Rep 2006/024

Dill LM, Heithaus MR, Walters CJ (2003) Behaviorally mediated indirect interactions in marine communities and their conservation implications. Ecology 84:1151-1157

$>$ Duggins DO (1983) Starfish predation and the creation of mosaic patterns in a kelp-dominated community. Ecology 64:1610-1619

Dumas JV, Witman JD (1993) Predation by herring gulls (Larus argentatus Coues) on two rocky intertidal crab species [Carcinus maenas (L.) \& Cancer irroratus Say]. J Exp Mar Biol Ecol 169:89-101

> Dvoretsky AG, Dvoretsky VG (2008) Epifauna associated with the northern stone crab Lithodes maia in the Barents Sea. Polar Biol 31:1149-1152

> Dvoretsky AG, Dvoretsky VG (2009) Epifauna associated with an introduced crab in the Barents Sea: a 5-year study. ICES J Mar Sci 67:204-214

Dvoretsky AG, Dvoretsky VG (2010) The amphipod Ischyrocerus commensalis on the eggs of the red king crab Paralithodes camtschaticus: egg predator or scavenger? Aquaculture 298:185-189

Ebert DA, Ebert TB (2005) Reproduction, diet and habitat use of leopard sharks, Triakis semifasciata (Girard), in Humboldt Bay, California, USA. Mar Freshw Res 56: 1089-1098

Eggleston DB, Lipcius RR, Grover JJ (1997) Predator and shelter-size effects on coral reef fish and spiny lobster prey. Mar Ecol Prog Ser 149:43-59

Elner RW, Campbell A (1987) Natural diets of lobster Homarus americanus from barren ground and macroalgal habitats off southwestern Nova Scotia, Canada. PSZN I: Mar Ecol 37:131-140

- Elner RW, Vadas RL Sr (1990) Inference in ecology: the sea urchin phenomenon in the northwestern Atlantic. Am Nat 136:108-125

- Estes JA, Riedman ML, Staedler MM, Tinker MT, Lyon BE (2003) Individual variation in prey selection by sea otters: patterns, causes, and implications. J Anim Ecol 72: 144-155

Estes JA, Terborgh J, Brashares JS, Power ME and others (2011) Trophic downgrading of Planet Earth. Science 333:301-306

Frank K, Petrie B, Choi J, Leggett WC (2005) Trophic cascades in a formerly cod-dominated ecosystem. Science 308:1621-1623

Garcia SM, Zerbi A, Aliaume C, Do Chi T, Lasserre G (2003) The ecosystem approach to fisheries. FAO, Rome

Gendron L, Archambault J (1997) Change in fishing capacity in the American lobster (Homarus americanus) fishery of the Magdalen Islands (Québec) from 1975 to 1995. Can Tech Rep Fish Aquat Sci 2189

Gendron L, Camirand R, Archambault J (2000) Knowledgesharing between fishers and scientists: towards a better 
understanding of the status of lobster stocks in the Magdalen Islands. In: Neis B, Felt L (eds) Finding our sea legs. ISER Books - Faculty of Arts Publications, St. John's, NL, p 56-71

Gendron L, Fradette P, Godbout G (2001) The importance of rock crab (Cancer irroratus) for growth, condition and ovary development of adult American lobster (Homarus americanus). J Exp Mar Biol Ecol 262:221-241

> Geraldi NR, Wahle RA, Dunnington M (2009) Habitat effects on American lobster (Homarus americanus) movement and density: insights from georeferenced trap arrays, seabed mapping, and tagging. Can J Fish Aquat Sci 66: $460-470$

Goodman-Lowe GD (1998) Diet of the Hawaiian monk seal (Monachus schauinslandi) from the Northwestern Hawaiian islands during 1991 to 1994. Mar Biol 132: 535-546

> Grabowski JH, Gaudette J, Clesceri EJ, Yund PO (2009) The role of food limitation in lobster population dynamics in coastal Maine, United States, and New Brunswick, Canada. NZ J Mar Freshw Res 43:185-193

Grosholz ED, Ruiz G (1996) Predicting the impact of introduced marine species: lessons from the multiple invasions of the European green crab Carcinus maenas. Biol Conserv 78:59-66

Haefner PA Jr, Shuster CN Jr (1964) Length increments during terminal molt of female blue crab, Callinectes sapidus, in different salinity environments. Chesap Sci 5: $114-118$

Hanson JM (2009) Predator-prey interactions of American lobster (Homarus americanus) in the southern Gulf of St. Lawrence, Canada. NZ J Mar Freshw Res 43:69-88

Hanson JM, Chouinard GA (2002) Diet of Atlantic cod in the southern Gulf of St. Lawrence as an index of ecosystem change, 1959-2000. J Fish Biol 60:902-922

Hanson JM, Lanteigne M (2000) Evaluation of Atlantic cod predation on American lobster in the southern Gulf of St. Lawrence, with comments on other potential fish predators. Trans Am Fish Soc 129:13-29

> Heithaus MR, Frid A, Wirsing AJ, Worm B (2008) Predicting ecological consequences of marine top predator declines. Trends Ecol Evol 23:202-210

Herrnkind W (1969) Queuing behavior of spiny lobster. Science 164:1425-1427

Higgins K, Hastings A, Sarvela JN, Botsford LW (1997) Stochastic dynamics and dereministic skeletons: population behavior of Dungeness crab. Science 276:1431-1435

Hines AH, Ruiz GM (1995) Temporal variation in juvenile blue crab mortality, nearshore shallows and cannibalism in Chesapeake Bay. Bull Mar Sci 57:884-901

Hjelset AM, Pinchukov MA, Sundet JH (2003) Joint report for 2003 on the red king crab (Paralithodes camtschaticus) investigations in the Barents Sea. Report to the $32 \mathrm{~h}$ Session for the Mixed Russian-Norwegian Fisheries Commission

Holsman KK, McDonald PS, Barreyro PA, Armstrong DA (2010) Restoration through eradication? Removal of an invasive bioengineer restores some habitat function for a native predator. Ecol Appl 20:2249-2262

Hoskin MG, Coleman RA, von Carlshausen E, Davis CM (2011) Variable population responses by large decapod crustaceans to the establishment of a temperate marine no-take zone. Can J Fish Aquat Sci 68:185-200

Ianelli JN, Honkalehto T, Barbeaux S, Kotwicki S, Aydin K, Williamson N (2011) Assessment of the walleye pollock stock in the Eastern Bering Sea. In: Stock assessment and fishery evaluation report for the groundfish resources of the Bering Sea/Aleutian Islands regions. Alaska Fisheries Science Center, National Marine Fisheries Service, North Pacific Fish Management Council, Anchorage, AK, p 51-168

Jackson JBC, Kirby MX, Berger WH, Bjorndal KA and others (2001) Historical overfishing and the recent collapse of coastal ecosystems. Science 293:629-637

> Jennings S, Kaiser MJ (1998) The effects of fishing on marine ecosystems. Adv Mar Biol 34:201-352

Jewett SC (1982) Predation on crabs of the genus Chionoecetes: a literature review. In: Proc Int Symp Genus Chionoecetes. Alaska Sea Grant College Program, University of Fairbanks, AK, p 521-538

Jewett SC, Feder HM (1982) Food and feeding habits of the king crab Paralithodes camtschatica near Kodiak Island, Alaska. Mar Biol 66:243-250

> Jones PL, Shulman MJ (2008) Subtidal-intertidal trophic links: American lobsters [Homarus americanus (MilneEdwards)] forage in the intertidal zone on nocturnal high tides. J Exp Mar Biol Ecol 361:98-103

Jørgensen LL (2005) Impact scenario for an introduced decapod on Arctic epibenthic communities. Biol Invasions 7 : 949-957

Jørgensen LL, Primicerio R (2007) Impact scenario for the invasive red king crab Paralithodes camtschaticus (Tilesius, 1815) (Reptantia, Lithodidae) on Norwegian, native, epibenthic prey. Hydrobiologia 590:47-54

> Kaiser MJ, Clarke KR, Hinz H, Austen MCV, Somerfield PJ, Karakassis I (2006) Global analysis of response and recovery of benthic biota to fishing. Mar Ecol Prog Ser 311:1-14

Karnofsky EG, Price HJ (1989) Dominance, territoriality and mating in the lobster, Homarus americanus: a mesocosm study. Mar Behav Physiol 15:101-121

> Kelly S, Scott D, Macdiarmid AB, Babcock RC (2000) Spiny lobster, Jasus edwardsii, recovery in New Zealand marine reserves. Biol Conserv 92:359-369

Kerr V, Grace RV (2005) Intertidal and subtidal habitats of Mimiwhangata Marine Park and adjacent shelf. Department of Conservation Research and Development Series 201, Wellington. Available at: www.conservation.net.nz/ upload/documents/science-and-technical/drds201.pdf

Klassen G, Locke A (2007) A biological synopsis of the European green crab, Carcinus maenas. Can Manuscr Rep Fish Aquat Sci 2818

> Lafferty KD (2004) Fishing for lobsters indirectly increases epidemics in sea urchins. Ecol Appl 14:1566-1573

- Lavalli KL, Herrnkind WF (2009) Collective defense by spiny lobster (Panulirus argus) against triggerfish (Balistes capriscus): effects of number of attackers and defenders. NZ J Mar Freshw Res 43:15-28

Lawton P (1987) Diel activity and foraging behavior of juvenile American lobsters, Homarus americanus. Can J Fish Aquat Sci 44:1195-1205

Lawton P, Lavalli KL (1995) Postlarval, juvenile, adolescent, and adult ecology. In: Factor JR (ed) Biology of the lobster Homarus americanus. Academic Press, San Diego, CA, p 47-88

Lowe S, Browne M, Boudjelas S, De Poorter M (2000) 100 of the world's worst invasive alien species: a selection from the global invasive species database. IUCN, Auckland

> MacDonald CD (1982) Predation by Hawaiian monk seals on spiny lobsters. J Mammal 63:700

> Micheli F (1997) Effects of predator foraging behavior on patterns of prey mortality in marine soft bottoms. Ecol Monogr 67:203-224

Micheli F, Peterson CH (1999) Estuarine vegetated habitats 
as corridors for predator movements. Conserv Biol 13: 869-881

Micheli F, Peterson CH, Johnson GA, Mullineaux LS and others (2002) Predation structures communities at deepsea hydrothermal vents. Ecol Monogr 72:365-382

Moland E, Moland Olsen E, Andvord K, Atle Knutsen J, Stenseth NC (2011) Home range of European lobster (Homarus gammarus) in a marine reserve: implications for future reserve design. Can J Fish Aquat Sci 68: 1197-1210

Moss SA (1972) Tooth replacement and body growth rates in the smooth dogfish, Mustelus canis (Mitchill). Copeia 1972:808-811

Myers A, Tlusty MF (2009) A long-term assessment of the physiological effects of herring (Clupea harengus) as a dietary component of the American lobster (Homarus americanus). NZ J Mar Freshw Res 43:173-183

> Novak M (2004) Diurnal activity in a group of gulf of Maine decapods. Crustaceana 77:603-620

> Orensanz JM, Armstrong J, Armstrong D, Hilborn R (1998) Crustacean resources are vulnerable to serial depletion the multifaceted decline of crab and shrimp fisheries in the greater Gulf of Alaska. Rev Fish Biol Fish 8:117-176

> Orlov YI, Ivanov BG (1978) On the introduction of the Kamchatka king crab Paralithoides camtschatica (Decapoda: Anomura: Lithodidae) into the Barents Sea. Mar Biol 48: 373-375

Paine RT (1994) Marine rocky shores and community ecology: an experimentalist's perspective. In: Kinne O (ed) Excellence in ecology, Book 4. International Ecology Institute, Oldendorf/Luhe

Palma AT, Wahle RA, Steneck RS (1998) Different early post-settlement strategies between American lobsters Homarus americanus and rock crabs Cancer irroratus in the Gulf of Maine. Mar Ecol Prog Ser 162:215-225

> Palma AT, Steneck RS, Wilson J (1999) Settlement-driven, multiscale demographic patterns of large benthic decapods in the Gulf of Maine. J Exp Mar Biol Ecol 241: 107-136

Pauly D, Christensen V, Dalsgaard J, Froese R, Torres FC Jr (1998) Fishing down marine food webs. Science 279: 860-863

Pedersen OP, Nilssen EM, Jørgensen LL, Slagstad D (2006) Advection of the red king crab larvae on the coast of North Norway: a Lagrangian model study. Fish Res 79: 325-336

> Pezzack DS (1992) A review of lobster (Homarus americanus) landing trends in the Northwest Atlantic, 1947-86. J Northwest Atl Fish Sci 14:115-127

Pezzack DS, Frail CF, Lawton P, Robichaud DA, Strong MB (2001) Update on stock status of American lobster, Homarus americanus, lobster fishing area 34. DFO Can Sci Advis Sec Res Doc 2001/156

Power M, Tilman D, Estes J, Menge B and others (1996) Challenges in the quest for keystones. Bioscience 46: 609-620

Quijón PA, Snelgrove PVR (2005a) Differential regulatory roles of crustacean predators in a sub-arctic, soft-sediment system. Mar Ecol Prog Ser 285:137-149

Quijón PA, Snelgrove PVR (2005b) Predation regulation of sedimentary faunal structure: potential effects of a fishery-induced switch in predators in a Newfoundland subarctic fjord. Oecologia 144:125-136

Richards RA, Cobb JS (1986) Competition for shelter between lobsters (Homarus americanus) and Jonah crabs (Cancer borealis): effects of relative size. Can J Fish Aquat Sci 43:2250-2255
Robichaud DA, Elner RW, Bailey RF (1991) Differential selection of crab Chionoecetes opilio and Hyas spp. as prey by sympatric cod Gadus morhua and thorny skate Raja radiata. Fish Bull 89:669-680

> Robles C (1987) Predator foraging characteristics and prey population structure on a sheltered shore. Ecology 68: 1502-1514

Robles CD (1997) Changing recruitment in constant species assemblages: implications for predation theory in intertidal communities. Ecology 78:1400-1414

Robles CD, Alvarado MA, Desharnais RA (2001) The shifting balance of littoral predator-prey interaction in regimes of hydrodynamic stress. Oecologia 128:142-152

Robles C, Robb J (1993) Varied carnivore effects and the prevalence algal turfs of intertidal. J Exp Mar Biol Ecol 166:65-91

> Robles C, Sweetnam D, Eminike J (1990) Lobster predation on mussels: shore-level differences in prey vulnerability and predator preference. Ecology 71:1564-1577

Rossong MA, Williams PJ, Comeau M, Mitchell SC, Apaloo $\mathrm{J}$ (2006) Agonistic interactions between the invasive green crab, Carcinus maenas (Linnaeus) and juvenile American lobster, Homarus americanus (Milne Edwards). J Exp Mar Biol Ecol 329:281-288

Rountree RA, Able KW (1996) Seasonal abundance, growth, and foraging habits of juvenile smooth dogfish, Mustelus canis, in a New Jersey estuary. Fish Bull 94:522-534

Rowe S (2001) Movement and harvesting mortality of American lobsters (Homarus americanus) tagged inside and outside no-take reserves in Bonavista Bay, Newfoundland. Can J Fish Aquat Sci 58:1336-1346

Rowe S (2002) Population parameters of American lobster inside and outside no-take reserves in Bonavista Bay, Newfoundland. Fish Res 56:167-175

> Saila SB, Nixon SW, Oviatt CA (2002) Does lobster trap bait influence the Maine inshore trap fishery? N Am J Fish Manag 22:602-605

Sainte-Marie B, Chabot D (2002) Ontogenetic shifts in natural diet during benthic stages of American lobster (Homarus americanus), off the Magdalen Islands. Fish Bull 100:106-116

Sainte-Marie B, Hazel F (1992) Moulting and mating of snow crabs, Chionoecetes opilio (O. Fabricius), in shallow waters of the northwestern Gulf of Saint Lawrence. Can J Fish Aquat Sci 49:1282-1293

> Sainte-Marie B, Raymond S, Brethes JF (1995) Growth and maturation of the benthic stages of male snow crab, Chionoecetes opilio (Brachyura: Majidae). Can J Fish Aquat Sci 52:903-924

Scrivener JCE (1971) Agonistic behavior of the American lobster, Homarus americanus (Milne-Edwards). Fish Res Board Can Tech Rep 235:1-128

Shanks AL, Roegner GC (2007) Recruitment limitation in Dungeness crab populations is driven by variation in atmospheric forcing. Ecology 88:1726-1737

Shears NT, Babcock RC (2002) Marine reserves demonstrate top-down control of community structure on temperate reefs. Oecologia 132:131-142

> Shears NT, Babcock RC (2003) Continuing trophic cascade effects after 25 years of no-take marine reserve protection. Mar Ecol Prog Ser 246:1-16

> Shears NT, Grace RV, Usmar NR, Kerr V, Babcock RC (2006) Long-term trends in lobster populations in a partially protected vs. no-take Marine Park. Biol Conserv 132: 222-231

Shurin JB, Borer ET, Seabloom EW, Anderson K and others (2002) A cross-ecosystem comparison of the strength of 
trophic cascades. Ecol Lett 5:785-791

Siddon C, Witman J (2004) Behavioral indirect interactions: multiple predator effects and prey switching in the rocky subtidal. Ecology 85:2938-2945

Silliman BR, Bertness MD (2002) A trophic cascade regulates salt marsh primary production. Proc Natl Acad Sci USA 99:10500-10505

Smith CR, Grange LJ, Honig DL, Naudts L, Huber B, Guidi L, Domack E (2012) A large population of king crabs in Palmer Deep on the west Antarctic Peninsula shelf and potential invasive impacts. Proc R Soc Lond B Biol Sci 279:1017-1026

Sneddon L, Huntingford FA, Taylor AC (1997a) Weapon size versus body size as a predictor of winning in fights between shore crabs, Carcinus maenas (L.). Behav Ecol Sociobiol 41:237-242

Sneddon L, Huntingford FA, Taylor AC (1997b) The influence of resource value on the agonistic behaviour of the shore crab, Carcinus maenas (L.). Mar Freshwat Behav Physiol 30:225-237

Squires HJ, Dawe EG (2003) Stomach contents of snow crab (Chionoecetes opilio, Decapoda, Brachyura) from the Northeast Newfoundland Shelf. J Northwest Atl Fish Sci 32:27-38

Steneck RS (1997) Fisheries-induced biological changes to the structure and function of the Gulf of Maine ecosystem. In: Wallace GT, Braasch EF (eds) Proc Gulf of Maine Ecosyst Dyn Sci Symp Workshop. Regional Association for the Research on the Gulf of Maine (RARGOM) Rep 91-1, Hanover, NH

Steneck RS (2006) Is the American lobster, Homarus americanus, overfished? A review of overfishing with an ecologically based perspective. Bull Mar Sci 78:607-632

Steneck RS, Vavrinec J, Leland AV (2004) Accelerating trophic-level dysfunction in kelp forest ecosystems of the western North Atlantic. Ecosystems 7:323-332

Steneck RS, Hughes TP, Cinner JE, Adger WN and others (2011) Creation of a gilded trap by the high economic value of the Maine lobster fishery. Conserv Biol 25: 904-912

Stevens BG, Armstrong DA, Cusimano R (1982) Feeding habits of the Dungeness crab Cancer magister as determined by the index of relative importance. Mar Biol 72 : 135-145

Taylor GM (2000) Maximum force production: why are crabs so strong? Proc R Soc Lond B Biol Sci 267:1475-1480

Tegner MJ, Dayton PK (1981) Population structure, recruitment and mortality of two sea urchins (Strongylocentrotus fanciscanus and $S$. purpuratus) in a kelp forest. Mar Ecol Prog Ser 5:255-268

> Tegner MJ, Levin L (1983) Spiny lobsters and sea urchins: analysis of a predator-prey interaction. J Exp Mar Biol Ecol 73:125-150

Thatje S, Anger K, Calcagno JA, Lovrich GA, Pörtner $\mathrm{H}$, Arntz WE (2005) Challenging the cold: crabs reconquer the Antarctic. Ecology 86:619-625

Torchin ME, Lafferty KD, Kuris AM (2001) Release from parasites as natural enemies: increased performance of a globally introduced marine crab. Biol Invasions 3: 333-345

Tremblay MJ, Smith SJ (2001) Lobster (Homarus americanus) catchability in different habitats in late spring and early fall. Mar Freshw Res 52:1321-1331
Vadas RL, Elner RW, Garwood PE, Babb IG (1986) Experimental evaluation of aggregation behavior in the sea urchin Strongylocentrotus droebachiensis. Mar Biol 90: 433-448

Valiela I, Teal JM (1979) The nitrogen budget of a salt marsh ecosystem. Nature 280:652-656

- Waddington KI, Meeuwig JJ (2009) Contribution of bait to lobster production in an oligotrophic marine ecosystem as determined using a mass balance model. Fish Res 99: $1-6$

Waddington KI, Bellchambers LM, Vanderklift MA, Walker DI (2008) Western rock lobsters (Panulirus cygnus) in Western Australian deep coastal ecosystems (35-60 m) are more carnivorous than those in shallow coastal ecosystems. Estuar Coast Shelf Sci 79:114-120

- Wahle R (1992) Body-size dependent anti-predator mechanisms of the American lobster. Oikos 65:52-60

Wahle RA (2003) Revealing stock-recruitment relationships in lobsters and crabs: is experimental ecology the key? Fish Res 65:3-32

Walker G (1974) The occurrence, distribution and attachment of the pedunculate barnacle Octolasmis mulleri (Coker) on the gills of crabs, particularly the blue crab, Callinectes sapidus Rathbun. Biol Bull (Woods Hole) 147: 678-689

- Walters C, Christensen V, Pauly D (1997) Structuring dynamic models of exploited ecosystems from trophic mass-balance assessments. Rev Fish Biol Fish 7: 139-172

Wells RJ, Steneck RS, Palma AT (2010) Three-dimensional resource partitioning between American lobster (Homarus americanus) and rock crab (Cancer irroratus) in a subtidal kelp forest. J Exp Mar Biol Ecol 384:1-6

Wickham DE (1986) Epizootic infestations by nemertean brood parasites on commercially important crustaceans. Can J Fish Aquat Sci 43:2295-2302

Wickham DE, Kuris AM (1988) Diversity among nemertean egg predators of decapod crustaceans. Hydrobiologia 156:23-30

- Wieczorek SK, Hooper RG (1995) Relationship between diet and food availability in the snow crab Chionoecetes opilio (O. Fabricius) in Bonne Bay, Newfoundland. J Crustac Biol 15:236-247

> Williams P, Floyd T, Rossong M (2006) Agonistic interactions between invasive green crabs, Carcinus maenas (Linnaeus), and sub-adult American lobsters, Homarus americanus (Milne Edwards). J Exp Mar Biol Ecol 329: $66-74$

- Worm B, Myers RA (2003) Meta-analysis of cod-shrimp interactions reveals top-down control in oceanic food webs. Ecology 84:162-173

Worm B, Lotze HK, Myers RA (2007) Ecosystem effects of fishing and whaling in the North Pacific and Atlantic Ocean. In: Estes JA, Brownell RL, DeMaster DP, Doak DF, Williams TM (eds) Whales, whaling and ocean ecosystems. University of California Press, Berkley, CA, p 335-343

Worm B, Hilborn R, Baum JK, Branch TA and others (2009) Rebuilding global fisheries. Science 325:578-585

> Zhang Y, Chen Y (2007) Modeling and evaluating ecosystem in 1980s and 1990s for American lobster (Homarus americanus) in the Gulf of Maine. Ecol Model 203: 475-489

Proofs received from author(s): September 17, 2012 